Kodifikasia : Jurnal Penelitian Islam, Vol 14, No. 01 (2020), 1-20

DOI : 10.21154/kodifikasia.v14i1.1892

ISSN : 1907-6371 (Cetak)

ISSN : 2527-9254 (Online)

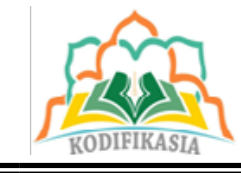

\title{
OTORITAS SPRITUAL DI ERA SYARIAT JARINGAN DAN KONTESTASI TAREKAT DALAM MASYARAKAT ACEH KONTEMPORER
}

\author{
Sehat Ihsan Shadiqin*, Aida Hayani**
}

\begin{abstract}
ABSTRAK:
Hadirnya teknologi telah memberikan dampak negatif bagi sebagian orang yang tidak dapat memanfaatkannya dengan baik. Selain itu zaman modern yang dianggap sebagai zaman yang menyebabkan seseorang untuk terjebak pada pola hidup materialistik-hendonistik yang mendorong dirinya lebih banyak menghabiskan hidupnya untuk mencari kepuasan yang bersifat materi dan sering kali bersifat tak acuh kepada Tuhannya. Penerapan syariat Islam di Aceh selalu terkait dengan hukum Islam. Hal ini telah menafikan aspek spritualitas dalam tarekat yang merupakan akar Islam di Aceh, apalagi kelompok-kelompok tarekat seperti tidak menampakkan diri kepermukaan. Namun yang menjad ipertanyaan apakah kelompok tarekat benar-benar hilang karena diberlakukan syari'at Islam. Tulisan ini mencoba menelusuri bagaimana pola adaptasi dan perubahan gerakan tarekat di Aceh pasca modern, dimana penulis mengambil contoh pada Majelis Pengkajian Tauhid Tasawuf (MPTT) Syekh Haji Amran Wali sebagai representasi tarekat Naqsyabandi al-Khalidi (Aceh Selatan dan Banda Aceh). Dari penelusuran ini, penulis menemukan beberapa pola adaptasi tarekat terhadap kebijakan dan kecenderungan masyarakat Islam dalam hukum Islam. MPTT Amran Wali cenderung melakukan pemaknaan ulang atas doktrin-doktrin tasawuf klasik yang dianggap bertentangan dengan syariat namun berbeda dengan lainnya.
\end{abstract}

Keyword: Tarekat; Syari'at Islam; Aceh

\footnotetext{
* Universitas Islam Negeri Ar-Raniry Banda Aceh, Email: sehatihsan@ar-raniry.ac.id ** Universitas Islam Negeri Sunan Kalijaga Yogyakarta, email: aidaalmahira@yahoo. com
} 


\begin{abstract}
:
The existence of technology has had a negative impact on some people who cannot use it wisely. In addition, modern era is considered as the period that caused peoples to get caught up in a materialistic-hendonistic lifestyle that drives them to spend more of their life looking for material satisfaction and ignored their God. The implementation of Islamic law in Aceh is always related to Islamic law. This has denied the spirituality aspect in the tarekat which is the root of Islam in Aceh, moreover tarekat groups are reluctant to appear on the surface. The question is whether the tarekat group was truly disappeared because of the implementation of sharia. This paper tries to explore how is the adaptation patterns and changes in the tarekat movement in post-modern Aceh, and the sample of this research is the Study of Tawheed Tasawuf (MPTT) Sheikh Haji Amran Wali as the representation of the Naqsyabandi al-Khalidi congregation (South Aceh and Banda Aceh). This study reveals several adaptation patterns of the tarekat to the policies and trends of the Islamic community in the implementation of Islamic law. MPTT Amran Wali tended to redefine classical Sufism doctrines that were considered to be contrary with the Sharia.
\end{abstract}

Keyword: Tarekat; Islamic Sharia; Aceh

\title{
PENDAHULUAN
}

Aceh adalah sebuah masyarakat yang menetap di ujung pulau Sumaterawilayah Indonesia. Hampir seluruh penduduk Aceh adalah beragama Islam yang taat.Selain itu, Aceh juga terkenal sebagai wilayah pertama sekali kemunculan Islam diAsia Tenggara. Aceh telah banyak melahirkan ulama-ulama yang telah berkembang dan tersebar kajian keislaman di Nusantara seperti Hamzah Fansuri, Syamsuddin As Sumatrani, Abdurrauf As Singkili dan Nuruddin Ar-Raniry.Masyarakat Aceh terkenal dengan ketaatannya terhadap agama dan sangat menjunjung tinggi budaya serta adat-istiadatnya. Sebelum Islam datang ke Aceh, pengaruh Hindu dan Budha sudah berakar dalam tradisi dan kepercayaan masyarakat Aceh. Oleh sebab itu walaupun Islam sudah berkembang dan maju di Aceh, terdapat beberapa budaya dan kepercayaan tradasional yang masih diamalkan oleh 
masyarakat Aceh yang berkaitan dengan ajaran Ahl al-Sunnah wa alJama'ah sebagai mazhab teologi masyarakat Aceh. ${ }^{1}$

Aceh dalam dekade ini didominasi oleh kajian mengenai konflik, perdamaian, bencana dan penanganan pascabencana, serta studi mengenai syari'at Islam. Hal ini tidak terlepas dari konteks sosial politik di Aceh pasca jatuhnya rezim orde baru 1998. Gerakan paling awal ditandai dengan bangkitnya "etnonasionalisme keacehan" dalam beragam variannya yang telah mendorong gerakan aceh merdeka (GAM). ${ }^{2}$ Kemudian pada tahun 2004 Aceh dilandai sebuah bencana alam gelombang tsunami yang memakan korban lebih dari 200 ribu jiwa manusia dan menghancurkan beberapa bagian kota. Setahun kemudian pemerintah Indonesia menandatangani MoU dengan perwakilan pasukan GAM melalui sebuah perundingan di Helsenki yang difasilitasi mantan presiden Finlandia, Marthi Athisaari. ${ }^{3}$ MoU ini telah melahirkan beberapa kesepakatan penting yang menjadi tonggak sejarah baru bagi Aceh di kemudian hari. Kondisi ini semua serta hal-hal lain yang berkaitan dengannya telah mendorong para peneliti dari berbagai bidang terkait dengan berbagai dispilin keilmuan pula. UU ini bertujuan untuk menegaskan bahwa Aceh adalah daerah istimewa yang berbeda dengan daerah lainnya. Sayangnya UU itu dianggap banyak pihak diberikan oleh pemerintah Indonesia setengah hati karena tidak secara implisit menyebutkan kewenangan tersebut. Bahkan banyak yang menduga pemerintah Indonesia memberikan UU ini tidak lain hanyalah untuk merendam pemberontak GAM yang mulai menguat saat itu. Oleh sebab itu UU disempurnakan kembali UU No 18 Tahun 2001 tentang otonomi khusus untuk daerahNanggroe Aceh Darussalam. Dengan UU yang baru, kewenangan Aceh melaksanakan syariat Islam sudah lebih jelas dan mungkin dilaksanakan walaupun masih ada berbagai kekurangan, namun yang pasti sejak saat itu Aceh resmi memberlakukan syariat Islam dengan mengeluarkanqanun yang dilandasi hukum Islam. ${ }^{4}$ Sementara berbagai kekurangan ini kemudian disempurnkan lagi dengan UU Nomor 11 Tahun 2006 tentang Pemerintah Aceh. Konteks sosial keagamaan ini telah menarik banyak peneliti untuk melakukan kajian tentang berbagai

\footnotetext{
${ }^{1}$ Muhammad Arifin, "Islam dan Akulturasi Budaya Lokal di Aceh," Jurnal Ilmiah ISLAM FUTURA 15(2) (2016): 251-84.

2 Otto Syamsuddin Ishak, Aceh Pasca Konflik: Kontestasi 3 Varian Nasionalisme (Banda Aceh: Bandar Publishing, 2015), 145.

${ }^{3}$ Martti Ahtisaari, "Lesson of Aceh Peace Talk," Asian Europe Journal 6(1) (2008): 9-14.

${ }^{4}$ Moch Nur Ichwan, "The Politics of Shariatization, Central Goverment and Religion Discourses of Sharia a Implementation in Aceh," in Islamic Law in Contempory Indonesia: Idea and Instituation, ed. oleh Micheal Feener dan Mark Cammack (Cambridge: Hardvard Law School and Harvard University Press, 2007), 193-215.
} 
dimensi sosial dan normatif penerapan hukum Islam tersebut. ${ }^{5}$ Fokus utama para peneliti adalah segala isu yang terkait dengan syariat Islam baik dalam kaitannya dengan regulasi maupun dengan kehidupan keseharian orang Aceh yang dikaitkan dengan regulasi syariat Islam. ${ }^{6}$

Apa yang terabaikan dalam kajian-kajian tentang Aceh dalam dekade ini adalah minimnya studi mengenai tasawuf dan gerakan tarekat dalam masyarakat Aceh sepanjang perubahan sosial keagamaan di Aceh tersebut. Padahal tarekat merupakan salah satu aspek penting dalam keberagaman masyarakat Aceh dan menjadi salah satu bagian dari kehidupan sosial mereka. Kita dapat menemukan pondok pesantren tarekat diberbagai wilayah Aceh yang dipimpin oleh khalifah dari Tarekat Naqsyabandiyah. Ditilik dari sejarah keagamaan pun tarekat juga menjadi bagian yang tidak dapat dipisahkan dari kehidupan sosial masyarakat aceh. Beberapa peneliti mengungkapkan kalau para sufi berperan penting dalam Islamisasi Nusantara termasuk Aceh. ${ }^{7}$ Oleh karena sejak masuk dan berkembang hingga saat ini, tasawuf juga masih menjadi unsur penting dalam kehidupan masyarakat Nusantara dan Aceh. ${ }^{8}$

Praktik hidup sufistik dan tarekat, yang pada awalnya lebih banyak dijumpai di daerah pedesaan. Kini sudah menjadi praktik keberagamaan yang populer bagi masyarakat Muslim menengah ke atas, terutama yang tinggal di daerah perkotaan.Praktik sufistik dan tarekat menjadi salah satu media untuk memenuhi sisi spiritualitas hidup yang belum terpenuhi melalui ibadah rutin. Di Indonesia, tarekat mulai berkembang sejak Abad ke-16 Masehi. Umumnya, perkembangan tarekat di Indonesia berasal dari luar, meskipun tidak sedikit ulama Indonesia menjadi bagian, sebagai pelaku utama meskipun tetap melalui jalur Mekah dan Madinah. Sementara di Aceh sendiri, perkembangan tarekat ini sangat luar biasa, seperti pada saat ini yaitu Tarekat Naqsabandiyah. ${ }^{9}$

${ }^{5}$ Kajian normatif biasanya dilakukan untuk menjelaskan tentang kebijakan penerapan syariat Islam atau memberikan sarat atau pandangan tentang model ideal pembelakuan syariat Islam itu sendiri. Lihat misalnya: Al-Yasa' Abu Bakar, Syariat Islam di provinsi Nanggroe Aceh Darussalam: Paradigma Kebijakan dan Kegiatan (Banda Aceh: Dinas Syariat Islam NAD, 2008), 23.

${ }^{6}$ Arskal Salim, Challengin the Secular State: The Islamization of Law in Modern Indonesia (Honolulu: Hawai University Press, 2008).David Kloss, "Becoming Better Muslims: Religious Authority and Ethical Improvement in Aceh, Indonesia" (Leiden University, 2013).

7 Anthony H. John, "Islamization in Southeast Asia: Reflection and Reconsiderations with Special reference to the Role Of Sufism," Southest Asian Studies 31(1) (1993): 46-61.

${ }^{8}$ Amirul Hadi, Islam and State in Sumatera: A Study of Seventeenth-Century Aceh (Leden: Brill, 2004), 148-49.

${ }^{9}$ E. Ova Siti Sofwatul Ummah, "Tarekat, Kesalehan Ritual, Spiritual dan Sosial: Praktik Pengamalan Tarekat Syadziliyah di Banten," Jurnal Pemikiran Islam dan Filsafat 15(2) (2018): 316.

Kodifikasia: Jurnal Penelitian Islam, Volume, 14 No. 1 Tahun 2020 
Tarekat yang memiliki pengaruh luas dalam masyarakat Aceh kontemporer adalah Tarekat Naqsabandiyah Khalidiyah. Tarekat ini pada awalnya dikembangkan oleh Muhammad Wali dari Labuhanhaji dikabupaten Aceh Selatan. Tarekat Naqsabandiyah Khalidiyah yang dibawa oleh Syaikh Muda Waly dikembangkan di Aceh melalui jalur pendidikan tradisional Islam pesantren, sehingga tidak heran terlihat inflitrasi tarekat yang sangat kuat ke dalam dunia pesantren di Aceh. Apalagi Syaikh Muda Waly juga berhasil menginspirasi bangkitnya kembali dunia pesantren di Aceh yang sempat hancur saat perang dengan Belanda. Ia mendirikan Pesantren Darussalam di Labuhanhaji, Aceh Selatan pada tahun 1940. Dengan demikian maka yang menjadi problema adalah otoritas spiritual di era syariat jaringan dan kontestasi tarekat dalam masyarakat Aceh kontemporer.

Dalam pandangan masyarakat Aceh kontemporer persoalan otoritas, terutama otoritas keagamaan, menjadi arena kontestasi berbagai kelompokkelompok keagamaan.Menurut Bourdieu, struktur juga terdapat dalam dunia sosial dan struktur objektif merupakan hal yang independen dari kesadaran dan kehendak agensi yang mampu menuntun atau membimbing praktik dan representasinya.Dengan menggenggam otoritas, tidak jarang tindakan-tindakan otoriter dipamerkan dengan menghakimi kelompok lain yang dianggap melenceng dari rel keagamaan yang dianggap mapan. Bukan hanya soal penghakiman "aliran sesat", otoritas juga sering digunakan untuk mengontrol pemeluk agama lain. Mengontrol di sini dimaksudkan untuk mengendalikan perilaku pemeluk agama lain yang dikhawatirkan mengancam agama pemilik otoritas itu. Dengan memegang otoritas, Tuhan seolah bersemayam dalam diri orang itu.Ucapan dan tindakannya dianggap mewakili ucapan dan tindakan Tuhan. Akibatnya, melawan ucapan dan tindakan pemegang otoritas dianggap sama dengan melawan ucapan dan tindakan Tuhan. Pada titik ekstrem ini, otoritas agama akan mengancam keragaman dalam kehidupan agama, baik keragaman pemahaman agama maupun keragaman ekspresi keagamaan. ${ }^{10} \mathrm{Kajian}$ ini akan sangat penting untuk melihat bagaimana tarekat berinteraksi dengan moderitas di Aceh, untuk melihat dinamika perkembangan sosial, politik dan keagamaan dalam tarekat Naqsabandiyah Khalidiy, maka dalam penelitian ini digunakan tiga konsep utama yakni otoritas spritual, tarekat Naqsabandiyah dan jaringan yang berhubngan dengan otoritas keagamaan.

\footnotetext{
${ }^{10}$ Rumadi, "Islam dan Otoritas Keagamaan," Jurnal Walisongo 20(1) (2012): 29.
} 


\section{PEMBAHASAN}

\section{Islam dan Perubahan Sosial di Aceh}

Era disrupsi melahirkan berbagai perubahan sosial yang berdampak ke berbagai lini kehidupan.Era Disrupsi menuntut siapa saja untuk mampu bersaing dan mengikuti ritme yang terus berjalan secara dinamis. Antara satu dimensi dengan dimensi yang lain, baik sosial, ekonomi, maupun budaya terus semakin berkelindan. Memang, awalnya era disrupsi identik dengan berbagai kontestasi perkembangan teknologi yang berimplikasi secara ekonomi.Namun lambat laun, hal tersebut telah merambah pada sudut pandang masyarakat di dalam berkehidupan sosial, temasuk sikap beragama. Disrupsi tidak hanya berhubungan dengan berbagai perubahanperubahan dalam aktivitas perekonomian yang mengharuskan pelaku ekonomi untuk berpikir dengan sudut pandang 'esok hari', melainkan juga erat kaitannya dengan berbagai tantangan kehidupan sosial masyarakat. ${ }^{11}$ Perubahan politik di Indonesia setelah kejatuhan rezim Orde Baru di bawah pimpinan Suharto tahun 1998 terasa di seluruh Indonesia. ${ }^{12}$

Di Aceh sendiri perubahan ini terlihat dari bangkitnya aspirasi masyarakat untuk menyelesaikan berbagai pelanggaran Hak Asasi Manusia (HAM) yang dilakukan oleh negara kepada rakyat Aceh selama pelaksanaan operasi jaring merah di bawah kebijakan pusat menetapkan status Daerah Operasi Militar (DOM) di Aceh. Aspirasi ini juga menjadi awal kemunculan -kembali- Gerakan Aceh Mereka (GAM) di bawah komando Muhammad Hasan Tiro yang telah mendeklarasikan Aceh Merdeka pada tahun 1976 di Gunung Halimun Kabupaten Pidie. Beberapa kelompok masyarakat di Aceh juga mengangkat kembali aspirasi lama masyarakat Aceh yang terus mendapatkan "pengkhianatan" oleh negara, yaitu pemberlakuan Syariat Islam secara kaffah untuk Aceh. Aspirasi ini sering menjadi argumen bahwa ide tentang Syariat Islam di Aceh memang berasal dari bawah (from below). ${ }^{3}$ Permintaan ini direspon oleh pemerintah dengan pengeluarkan UU No. 44 Tahun 1999 tentang keistimewaan Aceh.UU ini memberikan ruang kepada pemerintah Provinsi Aceh untuk melaksanakan Syariat

${ }^{11}$ Rizqa Ahmadi, "Kontestasi atas Otoritas Teks Suci Islam di Era Disrupsi : Bagaimana Kelas Menegah Muslim Indonesia Memperlakukan Hadis melalui Media Baru," Jurnal Studi Agama dan Masyarakat 1(15) (2019): 27.

${ }^{12}$ A.H. Johns, "Sufism as a Category in Indonesia Literature and History," Journal of South East Asian History 2(2) (1961).A

${ }^{13}$ Arskal Salim, "Syariah From Below in Aceh : Islamic Identity and the Right to Self Determination with Comparative Reference to The Moro Islamic Liberation Front (MILF),"Journal of Indonesian and Malay World 32 (92) (2004): 80-99.

Kodifikasia: Jurnal Penelitian Islam, Volume, 14 No. 1 Tahun 2020 
Islam.Pada tahun 2001 Pemerintah Republik Indonesia mengeluarkan UU No. 18 yang secara eksplisit menjelaskan tentang Syariat Islam di Aceh. ${ }^{14}$

Pelaksanaan Syariat Islam bukan sesuatu yang baru di wilayah Negara Kesatuan Republik Indonesia, terutama di daerah Aceh. Sejak sebelum kemerdekaan Republik Indonesia, daerah Aceh sudah dikenal dengan kerajaan Islam nya, seperti Samudera Pasai dan Kerajaan Aceh Darussalam dan sampai sekarang, syari'at Islam masih dipraktekkan oleh masyarakat provinsi Aceh. Namun demikian, dalam proses pelaksanaannya terdapat beberapa kendala yang disebabkan secara umum karena belum adanya format baku dan jelas yang dapat dijadikan panduan pelaksanaan di Aceh. Upaya-upaya mencari bentuk syari'at Islam di Aceh masih terus dilakukan hingga kini dalam segala bidang kehidupan, yang nantinya memberi warna sendiri dalam kajian hukum dan politik wilayah Negara Kesatuan Republik Indonesia. ${ }^{15}$

Islam merupakan bagian yang tidak terpisahkan dari kehidupan masyarakat Aceh. Sebuah pepatah Aceh mengatakan bahwa "agama dan adat bagaikan zat dan sifat". ${ }^{16} \mathrm{Hal}$ ini mengindikasikan kesatuan hakiki antara keduanya dalam kehidupan sosial masyarakat Aceh. Berbagai ritual budaya yang ada dalam masyarakat Aceh diyakini sebagai pengejawatahan dari nilai-nilai ajaran Islam. ${ }^{17}$ Namun demikian Islam di Aceh mengalami perubahan sesuai dengan perubahan sosial yang ada dalam masyarakat tersebut baik karena politik maupun karena bencana alam. ${ }^{18}$

Kedatangan Islam ke Aceh dijelaskan setidakanya dalam empat teori yakni Gujarat, teori persia, teori Arab dan teori Sufi. ${ }^{19}$ Ada beberapa ulama sufi yang menjadi bagian penting dalam kerajaan Aceh Darussalam pada abd XV yaitu Hamzah al-Fansuri, ${ }^{20}$ Syamsudiin dari Pasai. ${ }^{21}$ Nuruddin Arraniry dan Abdurrauf as-Singkili. Pada masa kerajaan tersebut Islam sebagai agama dalam kerajaan dan masyarakat dan menjadi pusat pengembangannya

\footnotetext{
${ }^{14}$ Kamaruzzaman bustamam Ahmad, "The Aplication of Islamic Law in Indonesia: The Case Study of Aceh," Journal of Indonesian Islam 1(1) (2007): 70.

${ }^{15}$ Syamsul Bahri, "Pelaksanaan Syari'at Islam di Aceh sebagai bagian wilayah Negara Kesatuan Republik Indonesia," Jurnal Dinamika Hukum 12(2) (2012): 1.

${ }^{16}$ Dalam bahasa Aceh "agama dengan adat lage zat dengon sifeut". Ismail, Sistem Budaya Adat Aceh dalam Membangun Kesejahteraan: Nilai Sejarah dan Dinamika Kekinian (Banda Aceh: Majelis Adat Aceh, 2008).

${ }^{17}$ Ali Hasymy, Sejarah Kebudayaan Aceh (Jakarta: Bulan Bintang, 1990).

${ }^{18}$ Arskal Salim dan Adlin Sila, Serambi Mekkah yanv Berubah View From Within, (Jakarta: ARTI-Alvabet, 2010)

${ }^{19}$ Alwi Syihab, Islam Sufistik, Islam Pertama dan pengaruh Hingga Kini di Indonesia (Bandung: Mizan, 2001).

${ }^{20}$ Syed Muhammad Naguib Al-Attas, The Mysticim of Hamzah Fansuri (Kuala Lumpur: University of Malaysa Press, 1970).

${ }^{21}$ Lihat Abdul Aziz Dahlan, "Thasawuf Syamsyuddin Sumartani” (IAIN Syarif Hidayatullah, 1992).
} 
Nusantara. Sejarah mencatat kalau Kerajaan Aceh Darussalam adalah kerajaan yang sangat komit dan tergila-gila dengan tasawuf. Sehingga banyak istilah dalam pemerintahan dan tata kota menggunakan istilah tasawuf. Misalnya pada istana sultan dinamai dengan Darul Kamal, sungai di taman istana bernama Darul 'Isyki, benteng istana disebut Kota Khalwat dan bahkan kapal kerajaan yang digunakan raja untuk pesiar atau mengunjungi daerah jauh dinamakan Mir'atus Safa (cermin kesufian). Oleh sebab itu mendiskusikan hal-hal yang terkait dengan tasawuf dan tarekat bukanlah hal yang tabu dan asing dalam masyarakat Aceh saat itu. ${ }^{22}$

Memiliki sejarah Islam awal membuat masyarakat Aceh ingin menjadikan hukum islam berlaku dalam kehidupan sosial masyarakat Aceh. Perjuangan ini terkadang dilakukan dengan senjata. Pada tahun 1959 Daud Bereuh memproklamasikan diri sebagai bagian dari negeri Islam Indoensia yang dideklarasikan oleh Kartosuwiyo di Jawa Barat setelah presiden Soekarno tidak memberikan izin Aceh menerapkan hukum Islam. Pada tahun 1976 Aceh kembali menjadi pembicaraan karena proklamasi kemerdekaan yang dilakukan oleh Muhammad Hasan Tiro, meskipun isu utama saat itu bukan lagi syariat Islam. Namun ketika gerakan ini bangkit untuk kedua kalinya tahun 1998, pemerintah Jakarta menangkap adanya semangat memberlakukan syariat Islam dalam gerakan Hasan Tiro. Oleh karena itu, pada tahun 1999 pemerintah mengeluarkan UU No 44 Tahun 1999, UU ini disempurnakan dengan UU No.18 Tahun 2001.

Dengan mengacu pada UU No.18 Tahun 2001 pemerintah Aceh mulai membuat Qanun tentang pemberlakuan syariat Islam. Qanun pertama terkait dengan pemberlakuan hukum Islam ini adalah qanun No 11 tahun 2001, qanun No 12 tahun 2003, qanun No 13 tahun 2003 dan qanun No 14 tahun 2003. Dalam qanun-qanun ini ditetapkan hukuman untuk pelanggar qanun adalah cambuk sehingga memunculkan perdebatan panjang dikalangan ahli hukum, masyarakat dan juga aktivis Hak Asasi Manusia (HAM) di dunia internasional. Meskipun demikian, sebagian masyarakat Islam Aceh sendiri memandang apa yang telah dibuat dalam qanun di atas sesungguhnya masih sangat terbatas, sehingga perlu qanun yang lebih kuat. Muncullah diskusi tentang qanun jinayah.

Diskusi tentang qanun jinayah ini mulai marak terjadi di Aceh setelah lahirnya Undang-undang No.11 Tahun 2006 tentang Pemerintah Aceh (UUPA). Pada Tanggal 23 Oktober 2015 Qanun No 6 Tahun 2014 tentang Hukum Jinayah dengan resmi diberlakukan setelah disahkan oleh DPRA dan ditandatangani oleh Gubernur Aceh, Zaini Abdullah. Selain masalah

${ }^{22}$ Sehat Ihsan Shadiqin, "Dibawah Payung Habib: Sejarah,Ritual, dan PolitikTarekat Syattariyah di Pantai Barat Aceh,” Jurnal Substantia 19(1) (2017): 78-79.

Kodifikasia: Jurnal Penelitian Islam, Volume, 14 No. 1 Tahun 2020 
syariat Islam hal lain yang berkembang di Aceh adalah masalah tarekat. Tarekat telah menjadi bagian dari kehidupan sosial di Aceh sejak masa Iskandar Muda. Namun karena berbagai faktor sosial beberapa tarekat yang telah berkembang pada masa lalu telah pudar dan bahkan hilang. Pun demikian, saat ini di Aceh yang bukan merupakan jaringan dari Tarekat Naqsyabandiyah Khalidiyah Muda Waly yaitu Tarekat Naqsyabandiyah yang dibawa Tgk. Muhammad Yatim di Lamno, Tarekat Nasyabandiyah Khalidiyah Qadirun Yahya dan Labai Sati Malalo dari Sumatera Barat. Ada juga beberapa tarekat Khalidyah seperti Naqsyabandiyah Nizamiyah, tarekat Qadariyah wa Nasyabandiyah.

\section{Posisi Muda Wali dalam Beragam Jaringan Tarekat di Aceh}

Tarekat Naqsyabandiyah merupakan tarekat yang sangat populer di Aceh saat ini, meskipun sebenarnya dalam sejarah tarekat Syattariyah yang berkembang luas di sana. ${ }^{23}$ Pada tahun 1939 Syaikh Muhammad Waly kembali dariPendidikannya diPadang, Sumatera Barat. ${ }^{24}$ Ia membawa sebuah oleh-oleh istimewa untuk masyarakat Aceh yakni Tarekat Nasyabandiyah Khalidiyah Muhammad Waly diperkirakan lahir pada tahun 1917. Orang tuanya bernama Malin Palito, berasal dari Padang yang merantau ke Aceh Selatan mengikuti jejak pamanya. Ia memulai pendidikan formal di VolksSchool di Labuhanhaji, sambil belajar di Pesantren Jami'atul Khariyah yang saat itu dipimpin oleh Tengku Muhammad Ali atau dikenal dengan Abi Lampisang. Lalu Muhammad Waly pindah ke pesantren Bustanul Huda yang juga dipimpin oleh ulama lain dari Aceh Besar yaitu Syekh Mahmud. Pada usia 16 tahun ia pergimeudagang (merantau untuk menuntut ilmu) ke Aceh Besar. ${ }^{25}$ Salah satu dayah yang terkenal pada saat itu adalah dayah yang dipimpin Hasan Krueng Kalee di desa Siem, Aceh Besar yang sudah terkenal sampai kampung di Aceh Selatan. ${ }^{26}$ Kemudian Muhammad Wali meninggalkan pesantren Hasballah Indrapuri yang masih berada di Aceh Besar. ${ }^{27}$ Setahun disana Hasballah kemudian merekomendasikan namanya untuk belajar ke Mesir dengan beasiswa Atjehsche Studie Fonds, sebuah

${ }^{23}$ Werner Kraus, "The Shattariyya Sufi Brotherhood in Aceh," in Aceh History Politics and Culture, ed. oleh Arndt Graf (Singapore: ISEAS, 2010), 201-26.

${ }^{24}$ Pada awal abd XX Sumatera Barat menjadi pusat pendidikan dan perkembangan Islam di Sumatera yang bahkan menyebar ke seluruh Indonesia. Lihat Deliar Noer, Gerakan Modern Islam di Indonesia:1900-1942 (Jakarta: LP3ES, 1990), 101.

${ }^{25}$ Kamaruzzaman Butaman-Ahmad, Acehnologi (Banda Aceh: Bandar Publishing, 2012).Mutia Zahara, "Tradisi Meugure Pada Dayah Perempuan di Aceh” (UIN Ar-Raniry, 2014), 25.

${ }^{26}$ Rusdi Sufi, Tgk. Hasan Krueng Kalee dan Teuku Nyak Arief, Profil Ulama dan Umara Aceh (Banda Aceh: Badan Perpustakaan Provinsi NAD, 2006), 45.

${ }^{27}$ Tentang Hasbalah Indrapuri lihat Ali Hasmy, Ulama Aceh Mujahid Kemerdekaan dan Pembangunan Tamaddun Bangsa (Jakarta: Bulan Bintang, 1997), 30. 
lembaga yang dibentuk oleh Tuanku Mahmud beserta beberapa uleebalang (bangsawan) lain di Aceh Besar tahun 1928. ${ }^{28}$ Ia segera dikrim ke Padang dengan beberapa penerima beasiswa yang lain untuk pembekalan di Normal Islamic School.

Muhammad Waly tidak betah disekolah tersebut dan melupakan niatnya pergi ke Mesir. Ia berkenalan dengan Khatib al-Fadani. ${ }^{29}$ Seorang ulama dari kelompok kaum yuo. Dari sana ia mulai bergaul di kalangan ulama Kaum Tuolainnya di Padang, seperti Sulaiman Rasuli ${ }^{30}$ dan Muhammad Jamil Jaho, ${ }^{31}$ yang bersama Khatib Ali mendirikan organisasi PERTI. Setahun kemudian ia berangkat ke Makkah bersama istrinya untuk menunaikan Ibadah Haji dan berkunjung ke beberapa ulama di sana. Sepulangnya, ia mengambil tarekat pada Syaikh Abdul Gani al-Kampari ${ }^{32}$ di Batu Basurek, Bankinang , Raiu. Tahun 1938 ia pulang dan mengajar disebuah dayah (surau, langgar) ${ }^{33}$ yang ada dikampung tersebut yang kemudian tumbuh menjadi pesantren besar yang dinamakan pesantren Darussalam.

Mulai tahun 1950-an jumlah santri yang belajar di Darussalam meningkat tajam. Sehingga setelah tahun 1960-an, alumni Darussalam

\footnotetext{
${ }^{28}$ Atjehsche Studie Fonds bertujuan memberikan bantuan pendidikan kepada anak-anak Aceh yang hendak meneruskan pendidikan. Organisasi ini diakui oleh Belanda menurut Gouverments besluit tanggal 1 Febuari 1929 No.25. organisasi ini sendiri didirikan oada 28 Mei 1928.

${ }^{29}$ Khatib Ali Lahir di Solok Selatan. Pada Usia 21 tahun ia berangkat ke Mekkah untuk pendidikan agama dan menunaikan Ibadah Haji dan menetap disana selama enam tahun. Selama di sana ia belajar pada beberapa ulama antara lain Syaikh Utsman Fauzi al-Khalidi Jabal Qais, Syaikh Sa'udasy Makkah, Syaikh Ahmad Ridhwan Madinah dan Syaikh Ahmad Khatib al-Minangkabawi. Ia kembali ke padang tahun 1905 dan menetap di Parak Gadang, Padang Timur. Pada tahun 1928 ia ikut serta menginisiasi berdirinya Persatuan Tarbiyah Islamiyah (Perti) di Sumatera Barat.

${ }^{30}$ Sulaiman al-Rusli adalah seorang ulama kaum tuo dan salah seorang pendiri PERTI di Sumatera Barat. Ia belajar di Makkah seangkatan dengan Kiyai Haji Hasyim Asyary yang menderikan Nahdatul Ulama (NU) di Jawa

${ }^{31}$ Muhammad Jamil Jaho adalah sahabat Sulaiman al-Rusli. Mereka sama-sama belajar di beberapa surau di Sumatera Barat dan sama-sama pula berangkat ke Makkah untuk menunaikan Ibadah haji dan memperdalam ilmu agama di sana selama 10 tahun . salah satu gurunya adalah Ahmad Khatib Minangkabau. Bersama Sulaiman al-Rusuli dan Syekh Abdul Karim Amrulah ia mendirikan Perguruan Islam Tawalib tahun 1922. Ia juga tercatat sebagai aktivitas Muhammadiyah.

${ }^{32}$ Martin Van Brunessen mengatakan ia mendapatkan pendidikan agama di Haramain dan menerima ijazah tarekat Naqsabandiyah dari Syaikh Sulaiman Zuhdi (dikenal pula dengan sebutan Syaikh Sulaiam Afandi). Sepulangnya dari Makkah, Ia mendirikan lembaga pendidikan agama di kampung halamanya, Kampar, Batu Basurek.

${ }^{33}$ Dalam Masyarakat Aceh ada dua kata yang hampir sama dayah dan deyah. Kata dayah adalah bahasa untuk pesantren sementara kata deyah adalah surau atau langgar yakni sebuah mushala kecil di dusunh Selatan.-dusun. Kata dayah sendiri hanya populer di masyarakat pantai Barat dan Selatan Aceh. Sementara dalam masyarakat pantai utara dikenal dengan sebutan meunasah. Saat ini kata dayah sudah sangat populer di Aceh dengan meningkatkanya etrasionalisme Aceh Pasca Kejatuhan Orde Baru tahun 1998.
}

Kodifikasia: Jurnal Penelitian Islam, Volume, 14 No. 1 Tahun 2020 
sudah tersebar di berbagai daerah di Aceh dan era baru pendidikan Islam tradisional di Aceh mulai bangkit. Kebangkitan itu nampak saat Muda Waly mulai terjun politik. Ia dengan tegas menentang pemberontakan Darul Islam yang digagas dan dipimpin Abu Daud Beuereueh tersebut, meskipun gerakan tersebut sangat kuat pada masa itu, ia juga terlibat dan aktif mengembangkan Persatuan Tarbiyah Islamiyah (PERTI).

Ia meninggal dunia pada usia yang masih sangat muda, 44 tahun. Namun pengaruh sangat besar, apalagi ada sebuah upaya membentuk karismanya sebagai tokoh besar di Aceh berkat jasa murid-muridnya. Ada beberapa jalan pembentukan karisma ini, antara lain melalui penulis Buku Biografi, penyebaran Poster Ulama Kharismatik Aceh dan pemberian gelar Agama dan Sosial kepadanya. Sejauh ini ia mendapatkan tiga gelar penting: yakni sebagai "Arif Billah, Toko Pendidikan, sebagai Syaikhul Islam di Aceh bersama dengan Hamzah Fansuri dan Muhammad Saman Tiro. Selain itu beredar pula banyak tulisan tentang beragam "karamah" yang ia miliki yang membuat nama Muda waly tumbuh menjadi sangat dikenal di Aceh.

Pengaruh besar membuat Naqsyabandiyah Khalidiyah Muda Waly berkembang pesat di Aceh. Hal ini menimbulkan semangat untuk mendominasi dari penerusnya. Oleh sebab itu muncul beberpa hubungan yang tidak elok dengan tarekat lain. Misalnya dengan jaringan Muhammmad Yatim di Lamno. Abuya Djamaluddin Waly, mursyid tarekat Naqsybandiyah Muda Waly pernah mengatakan kalau tarekat ini tidak benar atau tidak sesuai dengan tarekat Islam yang benar, namun kemudian beliau mengklarifikasi pandanganya.

Hal yang sama juga terjadi pada tarekat Naqsyabandiyah di bawah jaringan Qadariun Yahya yang berkembang di Aceh Timur. Meskipun antara dua jaringan ini memiliki akar yang sama, namun perebutan kuasa pengikut terkadang saling klaim kebenaran tidak terelakkan. Konflik lain yang sejennis terjadi dengan murid dari Labai Sati Malalo. Murid Palito adalah anak dari Muda Waly dari ibu yang berbeda dengan Muhibbuddin dan Djamaluddin. Semnetara dengan Naqsyabandiyah non-Khalidiyah seperti Tarekat Qadariyah wan Naqsyabandiyah dan Naqsyabandiyah Nizamiyah, nyaris tidak terjadi gesekan karena perbedaan yang jelas dan pengaruh yang kecil dari tarekat tersebut.

\section{Tarekat Dalam Kehidupan Sehari-hari Masyarakat Aceh}

Naqsyabandiyah mewarnai kehidupan keagamaan masyarakat Aceh, baik sebagai jamaah tarekat maupun bukan. Guru tarekat Naqsyabandiyah telah menjadi patron penting dalam berbagai praktik keagamaan di desa-desa 
dan menjadi orang yang otoritatif dalam menyimpulkan dan memutuskan banyak perkara keagamaan. ${ }^{34}$

Dibeberapa daerah di Aceh, semua ritual keagamaan yang dilaksanakan masyarakat desa, seperti memimpin samadiyah dan kenduri kematian, membaca talkin untuk orang yng baru dikuburkan dan membaca beberapa surat utama dal al-Qur'an harus mendapat pengesahan dari mursyid tarekat Naqsyabandiyah yang ada di daerah tersebut. Dengan demikian, praktik beragama masyarakat di desa selalu terkait dengan pandangan keagamaan mursyid-mursyid tarekat dalam jaringan Muda Waly dan dengan jalan ini pula Muda Waly mendapatkan tempat yang sangat terhormat dalam memori sosial masyarakat di Aceh.

Hubungan anatra Muda Waly dengan masyarakat biasa tercermin dalam beberapa perilaku sosial keagamaan jamah dan masyarajat yang dilakukan sehari-hari. Secara garis besar, ada tiga ritual pokok yang hidup dalam jamaah tarekat di Aceh yang dihubungkan langsung dengan Syaikh Muda Waly yakni ritual khas tarekat Naqsyabandiyah (suluk dan tawajjuh) kemudiah ziarah ke kubah yakni makam Syaikh Muda Waly yang terletak di tengah-tengah kompleks dayah Darussalam Labuhanhaji dan tarekat Samadiyah yakni bacaan tahlilan yang dilafazkan dalam kenduri kematian dalam masyarakat. Semua perilaku ini dihubungkan dengan Syaikh Muda Waly sebagai guru tarekat yang utama.

Prosesi tarekat Naqsyabandiyah Khalidiyah dalam kehidupan sosial masyarakat Aceh memiliki keberagaman dalam praktik, meskipun berasal dari sumber yang sama. Berbagai kelompok jamaah melakukan modifikasi beberapa aspek ritual yang ada, untuk menyesuaikan dengan konteks sosial yang mereka miliki, hubungan ini juga terjadi dalam relasi antara guru tarekat dan antar guru tarekat dengan pemerintah. Para tengku yang melakukan modifikasi ini memiliki pandangan yang kadangkala bukan pandangan para mursyid utama dalam tarekat tersebut. Meskipun mereka mengakui menjadi bagian dalam silsilah, namun mereka sebenarnya bukan yang orang benar-benar menempatkan tarekat sebagai bagian dari keberagamaan mereka sehari-hari. Dalam bagian ini akan dijelaskan dinamika praktik ritual tarekat dalam kehidupan sehari-hari masyarakat Aceh. Pada bagian awal akan dijelaskan struktur sosial tarekat yang menjadi media komunikasi dan koordinasi dalam tarekat Naqsyabandiyah Khalidiyah di Aceh.

${ }^{34}$ Sehat Ihsan Shadiqqin, "Tarekat Shiddiqiyah dalam Masyarakat Jawa Pedesaan," Jurnal Subtantia 14(2) (2012): 275.

Kodifikasia: Jurnal Penelitian Islam, Volume, 14 No. 1 Tahun 2020 
Jaringan Keguruan Tarekat Naqsyabandiyah Khalidiyah Muda Waly Jaringan keulamaan dalam dunia tarekat terbentuk karena hubungan guru murid yang sangat kuat, sehingga ide-ide keagamaan dapat tumbuh dari satu pusat pengembangan ilmu agama ke tempat lainnya. Jaringan ini juga menjadi ruh dalam tradisi tarekat yang tidak dapat dihilangkan sama sekali. ${ }^{35}$ Menghilangkan relasi guru dan murid berartu menajdi tarekat tidak lagi menjadi " tarekat" yang sesungguhnya. ${ }^{36}$ Rekasi ini bukan saja bermakna dalam pelimpahan ilmu dan otoritas, secara lebih luas juga dalam pengembangan ilmu pengetahuan Islam antar daerah. Seperti catat Azra dimana hubungan guru dan murid yang terjadi di kalangan ulama nusantara dalam abad XVII telah mampu mentrasnformasikan ilmu-ilmu keislaman yang berkembang di Haramain ke nusantara. Demikian juga muridmurid Abdurrauf as-Singkili menjadi pelopor perkembangan neosufisme yang direpresentasikan dalam tarekat Syattaiyah di Sumatera Barat dan Malaysia. ${ }^{37}$ Bahkan dalam banyak kasus hubungan guru dan murid dalam tarekat ini bersifat sangat duniawi, misalnya memperkuat jaringan sosial ekonomi, memperkuat dukungan politik dalam perkembangan tarekat di Cape Town, Afrika Sekatan menunjukkan jaringan keulamaan tarekat antara Samudera Hindia dan Asia Tenggara dengan Muslim lokal telah menjadi sarana untuk membangun pengakuan akan indentitas kewarganegaraan (citizenship). Dalam tarekat Naqsyabandiyah Khalidiyah yang berkembang di Aceh hubungan antara guru dan murid memiliki dinamika yang berbeda sesuai dengan periode perkembanganya. Dalam periode pertama, hubungan yang terbangun berorientasi untuk menguatkan ortoksi Islam di tengah masyarakat Aceh yang telah "termodernkan" saat itu dengan kehadiran alumni-alumni Sumatera Tawalib dan Muhammadiyah. Dalam periode kedua relasi yang identitas ortodoksi yang lebih kuat. Periode ketiga menguatkan identitas keguruan tarekat dalam jaringan pesantren di Aceh membangun kharisma kewalian pada sosok pembawa awal tarekat ini yakni Syaikh Muda Waly.

${ }^{35} \mathrm{Hal}$ ini disampaikan oleh banyak penulis awal tentang tarekat dalam tradisi tasawuf Ilsam, lihat antara lain : Martin Lings, What is Sufism? (London: Allen \& Unwin, 1975), 52.

${ }^{36}$ Rubaidah, "Reorientasi Idiologi Urban Sufisme di Indonesia terhadap Relasi Guru dan Murid dalam Tradisi Generik Sufism pada Majelis Shalawat Muhammad di Surabaya," Teosofi, Jounal Tasawuf dan pemikiran Islam 5(2) (2015): 294-320.

${ }^{37}$ Omae Fathurrahman, "Reinforching Neo-Sufism in The Malay Indonesia World: Stattariyah Order in West Sumatra," Studi Islamika: Indonesian Journal for Islamic Studies 10(3) (2003): 29-93. 


\section{Kontestasi Otoritas Spiritual}

Meskipun Muda Waly menempati posisi penting dan sentral dalam perkembangan pendidikan pesantren di Aceh dan tentu saja perkembangan Tarekat Naqsyabandiyah Kahlidiyah setelah ia mangkat beberapa konflik terjadi di dalam organisasi teraket tersebut, baik antara pengikut dengan mursyidnya atau antara muryid dalam tarekat. Konflik dan kontestasi dalam sebuah organisasi sesunguhnya dapat dilihat sebagai sebuah dinimika saja, namun ketika konflik dan kontestasi terjadi dalam organsiasi keagamaan, maka kita perlu mengajukan pertanyaan ada apa sesungguhnya? Sebab, tarekat meskipun sebagai sebuah organisasi tetap organisasi yang berafiliasi dengan agama. Bahkan lebih speksifik lagi tarekat berafiliasi dengan dimensi terdalam dalam sebuah agama yakni spiritualitas oleh karena itu ketika ada konflik dan kotestasi. Maka ini merupakan sebuah keanehan yang perlu di dalami kembali.

Kontestasi yang terjadi dalam tarekat ini memiliki beberapa penyebab pertama hubungan loyalitas mursyid dan murid. Meskipun seorang mursyid dalam tarekat merupakan orang yang harus diikuti dalam keadaan bagaimanapun, namun kenyataan tidaklah demikian. Mereka patuh untuk alasan kebersinambungan ilmu, memiliki hubungan darah dengan ulama, masuk dalam silsilah tarekat sebagai orang tua masyarakat dan karena ia memiliki kemuliaan di berikan kemuliaan oleh Allah Swt. Sebaliknya, loyalitas tidak diberikan karena beberapa perilaku yang dilakukan oleh mursyid yang tidak mencerminkan kemursyidannya.

Kontestasi dalam tarekat dimulai dari terbentuknya klaim otoritas kemursyidan pasca Muda waly wafat. Muhibuddin Waly memperkenalkan istilah Sayyidul Musyidin. Posisi ini ditetapkan karena darah artinya hanya akan diwarisi oleh anak keturunan Muda Waly semata, meskipun ada muridmuridnya yang senior dan sangat paham tarekat. Sementara mursyid "besar" yang tidak memiliki hubungan darah dengan Muda Waly hanya memimpin tarekat di daerah saja. Namun mereka memiliki pandangan yang berbeda tentang hal ini. Ada yang mereka tidak perlu mengakui adanya mursyid 'am dalam tarekat. Artinya sebuah tarekat bukanlah sebuah organisasi dimana harus ada seorang ketua besar dalam satu wilayah. Tarekat adalah sebuah jalan seseorang dan sekolmpok orang membangun jalan menuju Allah Swt. Namun adapula yang mengaku bahwa harus ada mursyid utama di sebuah daerah sepertiAceh. Apa yang berlangsung dalam sistem tarekat yang ada di Aceh saat ini memang sudah berjalan dengan jalur yang sesungguhnya. Seorang mursyid utama akan bertugas dan bertanggung jawab membaiat mursyid yang lain atau mursyid yang baru. Selama mereka masih ada, maka mursyid yang lain sejatinya hanya mengangkat seorang khalifah, munafiz 
atau seorang wakil mursyid saja. Dengan demikian, sebuah tarekat tidak akan dipenuhi oleh orang-orang yang bisa dengan mudah mengaku sebagai mursyid padahal ia bukan seorang mursyid yang sesunguhnya.

Sementara mursyid-mursyid non jaringan Muda Waly sering juga terlibat dalam kontestasi terkait dengan pengaruh dalam masyarakat. Salah satu kontestasi yang paling besar terjadi antara Abuya Djamaluddin Waly dan Amran Waly di Aceh. Secara langsung hal ini terlihat dalam debat panjang mereka terkait dengan isu wahdatul wujud yang dikembangkan oleh Amran Waly di Aceh. Namun dibalik perdebatan itu semua sesungguhnya terkandung motif politik, terutama terkait dengan otoritas dan jaringan keguruan di bawah keduanya.

\section{Bertahan dalam Perubahan: Kodomifikasi dan Afaliasi Politik Tarekat}

Sebuah organisasi sosial-keagamaan secara alamiah memiliki naluri untuk bertahan dalam perubahan sosial yang ada di sekitarnya. Demikian juga halnya dengan organisasi tarekat. Merupakan sebuah keniscayaan bagi organisasi tarekat untuk mengembangkan, memodifikasi serta mengaktualisasi doktrin sufi dan ritual tarekat saat berhadapan dengan perkembangan agama, kehidupan sosial dan dinamika politik. ${ }^{38} \mathrm{Hal}$ ini dilakukan agar mereka terus survive dalam perubahan tersebut. Ada banyak hal dapat dilakukan untuk menjaga tarekat agar dapat terus bertahan. Abd Syukur misalnya mengemukakan empat usaha yang dilakukan kelompok tarekat dalam rangka mempertahankan organisasi mereka yakni pembenahan organisasi, memanfaatkan kesempatan politik, mengemas aksi dalam bingkai idiologi dan membangun kesalehan sosial. ${ }^{39}$ Bukan hanya dalam kelembagaan tarekat, penyesuaian dengan perubahan zaman terkadang juga harus dilakukan oleh ulama atau kiyai dalam tarekat itu sendiri mengingat dalam beberapa strata sosial masyarakat di Indonesia telah terjadi sebuah krisis legistimasi pada kyai. ${ }^{40}$ Sehingga mereka sudah seharusnya mengubah reorientasi terhadap pola kepemimpinan yang diperankannya dari religo-paternalistik ke arah pola kepemimpinan partisipatif-persuatif. ${ }^{41}$

Hal lain yang dilakukan oleh organisasi tarekat adalah mendekatkan diri dengan kekuasaan. Hal ini memang bukan suatu hal yang baru mengingat

${ }^{38}$ Dudung Abdurahman, "Sosiologi Kaum Sufi: Sebuah Model Studi Intergratif Interkonektif," Jurnal Sosiologi Reflektif 9(2) (2015): 188.

${ }^{39}$ Abd Syukur, "Mekanisme Bertahan Kaum Tarekat," Islamica 4(2) (2010): 211-28.

${ }^{40}$ Edi Susanti, "Krisis Kepemimpinan Kiai atas Kharisma Kiai dalam Masyarakat," Jurnal Islamica 01(2) (2007): 111-20.

${ }^{41}$ Imron Arifin, "Kepemimpinan Kyai: Kasus Pondok Pesantren Tebuireng," Islami Studies, 2006, 211-68. 
tarekat dan politik telah menjamin hubungan saling menguntungkan sepanjang sejarah tarekat itu sendiri. Di Indonesia sendiri hal ini juga terjadi dengan dua variasi atau bentuk, aktif dan pasif. Varian aktif adalah varian dimana kyai tarekat mendekatkan diri pada kekuasaan dengan membawa nama tarekatnya sementara varian pasif adalah politis bergabung dengan tarekat dan menggunakan tarekat untuk mendapatkan dukungan memenangkan pemilihan umum.

Selain perubahan internal tarekat dan kedekatan tarekat dengan politik, tarekat juga telah bertransformasi dalam bentuk yang baru yang dikenalurban sufism. Kemunculan ini diikuti dengan tokoh-tokoh televangelis yang sangat populer di televisi dengan beragam gaya mereka. Bagi Howel hal ini adalah momen dimana sufisme di Indonesia telah berpindah dari sebelumnya berbentuk tarekat di pedesaan sekarang dengan bentuk urban sufism di perkotaan. Perbedaan sangat jelas dalam urban sufism tokoh utamanya tidak mendapatkan penghormatan berlebihan dari jamaah.

Aceh adalah suatu daerah yang berubah dengan sangat cepat, terutama dalam isu-isu sosial dan keagamaan. Dalam kondisi sosial demikian, maka perubahan modern di berbagai belahan dunia dan kota-kota lain juga masuk ke Aceh, termasuk di dalamnya cara bertarekat. Tarekat Naqsabandiyah Khalidiyah di Aceh dalam menghadapi tuntutan perubahan ini. Pertama membangun organisasi turunan non tarekat namun memiliki afiliasi berlangsung dengan tarekat Naqsabandiyah itu sendiri. Kedua, membangun afilasi politik dengan aktor-aktor politik lokal dalam membangun eksitensi mereka. Berbeda dengan apa yang umumnya terjadi di Indonesia, afaliasi dengan politik yang terjadi dalam tarekat di Aceh diwakili oleh organisasi turunanya, bukan oleh organisasi tarekat secara langsung. Ketiga, membangun sebuah struktur baru dalam tarekat Naqsabandiyah Khalidiyah di Aceh. Tiga pola adaptasi yang dilakukan tarekat Naqsabandiyah di atas tidak dapat dilepaskan dengan dinamika internal tarekat dan eksternal masyarakat Aceh secara umum.

\section{PENUTUP}

\section{Kesimpulan}

Tarekat merupakan bagian penting dalam tradisi keagamaan di Aceh, oleh karena itu, tidak mungkin mengabaikan dimensi ini ketika kita mempelajari Islam di Aceh kotemporer. Tarekat Naqsyabandiyah Khalidiyah yang dibawa oleh Syaikh Muda Waly al-Khalidi telah berkembang sangat cepat dan pesat dalam masyarakat kotomporer. Persebaran tarekat dibawa oleh Syaikh Muda Waly al-Khalidi di seluruh Aceh tidak terlepas dari dua jaringan 
murid beliau yaitu jaringan murid pesantren dan jaringan murid tarekat. Jaringan pertama adalah kelompok yang memperteguh dan menguatkan ide-ide ortodoksi Islam yang oleh Syaikh Muda Waly sebagai tokoh yang memiliki otoritas spritual dalam pelaksanaan agama Islam kepada masyarakat Aceh. Dengan cara ini, Syaikh Muda Waly mendapatkan kharismanya dan mengangkat derajat kewaliannya dalam masyarakat Aceh.Terbentuk jaringan keulamaan yang memiliki pola sangat beragam dalam pengembangan tarekat ini telah memunculkan konstestasi antara pemegang otoritas keagamaan dalam tarekat Naqsyabandiyah. Kontestasi utama terjadi antara mursyid-mursyid utama dalam tarekat Nqsyabandiyah Khalidiyah di Aceh dan antara mursyid dengan ulama lain yang berada dibawah naungannya. Kontestasi dalam tarekat Naqsyabandiyah Khalidiyah telah menggeser pola patronase otoratif yang lebih cair berazas pilihan rasional di kalangan jamaah tarekat Naqayabdiyah di Aceh.Kontestasi yang terjadi dalam tarekat telah menyebakan perbedaan respon yang diambil dalam mengahadapi perubahan sosial dan politik yang terjadi di Aceh. Setiap musryid memiliki otoritas besar dan pengikut banyak membuat organsisai dan setiap organisasi memiiki karakter dan kekhasan sendiri sesuai dengan tujuan gerakan tersebut. Melalui organsiasi inilah, mereka merespons perubahan sosial di Aceh. Dalam tarekat perubahan dilakukan dengan melakukan restrukturisasi kepengurusan dengan menambanhkan posisi "Musryidul "Aam" sebagai pemilik otoritas tertinggi dalam tarekat ini. Terlihat bahwa otoritas jaringan spiritual dalam penyebaran ide-ide keagamaan di Aceh atau peneliti menyebutknya denganSpiritual network authority (SNA). SNA terdiri dari patron (Mursyid) dank klien (Jamaah). Ketika patron utama tidak ada lagi (wafat), patron-patron menjadi penghuni menjadi pengendali otoritas baru dengan membentuk simpul-simpul baru dalam jaringan.Patron yang baru berkontestasi dalam memperebutkan otoritas spiritual dan keagamaan di kalangan jamaah.Kontestasi antar patron menyebabkan klien memberikan pilihan rasional dalam mengikuti patronya. Patron yang tersisih akan memperkuat diri dengan "membentuk charisma" tentang patron utama dan menyatakan diri sebagai pewaris paling otoritatif dari patron utama tersebut. 


\section{DAFTAR RUJUKAN}

Abd Syukur. "Mekanisme Bertahan Kaum Tarekat." Islamica 4(2) (2010).

Abdul Aziz Dahlan. "Thasawuf Syamsyuddin Sumartani." IAIN Syarif Hidayatullah, 1992.

Abdurahman, Dudung. "Sosiologi Kaum Sufi: Sebuah Model Studi Intergratif Interkonektif." Jurnal Sosiologi Reflektif 9(2) (2015).

Ahtisaari, Martti. "Lesson of Aceh Peace Talk." Asian Europe Journal 6(1) (2008).

Al-Yasa' Abu Bakar. Syariat Islam di provinsi Nanggroe Aceh Darussalam: Paradigma Kebijakan dan Kegiatan. Banda Aceh: Dinas Syariat Islam NAD, 2008.

Arifin, Imron. "Kepemimpinan Kyai: Kasus Pondok Pesantren Tebuireng." Islami Studies, 2006, 221-68.

Bahri, Syamsul. "Pelaksanaan Syari'at Islam di Aceh sebagai bagian wilayah Negara Kesatuan Republik Indonesia.” Jurnal Dinamika Hukum 12(2) (2012).

Hadi, Amirul. Islam and State in Sumatera: A Study of Seventeenth-Century Aceh. Leden: Brill, 2004.

Hasmy, Ali. Ulama Aceh Mujahid Kemerdekaan dan Pembangunan Tamaddun Bangsa. Jakarta: Bulan Bintang, 1997.

Hasymy, Ali. Sejarah Kebudayaan Aceh. Jakarta: Bulan Bintang, 1990.

Ichwan, Moch Nur. "The Politics of Shariatization, Central Goverment and Religion Discourses of Sharia a Implementation in Aceh." In Islamic Law in Contempory Indonesia: Idea and Instituation, diedit oleh Micheal Feener dan Mark Cammack. Cambridge: Hardvard Law School and Harvard University Press, 2007.

Ismail. Sistem Budaya Adat Aceh dalam Membangun Kesejahteraan: Nilai Sejarah dan Dinamika Kekinian. Banda Aceh: Majelis Adat Aceh, 2008. John, Anthony H. "Islamization in Southeast Asia: Reflection and Reconsiderations with Special reference to the Role Of Sufism." Southest Asian Studies 31(1) (1993). 
Johns, A.H. "Sufism as a Category in Indonesia Literature and History." Journal of South East Asian History 2(2) (1961).

Kamaruzzaman bustamam Ahmad. "The Aplication of Islamic Law in Indonesia: The Case Study of Aceh." Journal of Indonesian Islam 1(1) (2007).

Kamaruzzaman Butaman-Ahmad. Acehnologi. Banda Aceh: Bandar Publishing, 2012.

Kloss, David. "Becoming Better Muslims: Religious Authority and Ethical Improvement in Aceh, Indonesia.” Leiden University, 2013.

Lings, Martin. What is Sufism? London: Allen \& Unwin, 1975.

Muhammad Arifin. "Islam dan Akulturasi Budaya Lokal di Aceh." Jurnal Ilmiah ISLAM FUTURA 15(2) (2016).

Mutia Zahara. "Tradisi Meugure Pada Dayah Perempuan di Aceh." UIN Ar-Raniry, 2014.

Noer, Deliar. Gerakan Modern Islam di Indonesia:1900-1942. Jakarta: LP3ES, 1990.

Omae Fathurrahman. "Reinforching Neo-Sufism in The Malay Indonesia World: Stattariyah Order in West Sumatra." Studi Islamika: Indonesian Journal for Islamic Studies 10(3) (2003).

Otto Syamsuddin Ishak. Aceh Pasca Konflik: Kontestasi 3 Varian Nasionalisme. Banda Aceh: Bandar Publishing, 2015.

Rizqa Ahmadi. "Kontestasi atas Otoritas Teks Suci Islam di Era Disrupsi : Bagaimana Kelas Menegah Muslim Indonesia Memperlakukan Hadis melalui Media Baru." Jurnal Studi Agama dan Masyarakat 1(15) (2019).

Rubaidah. "Reorientasi Idiologi Urban Sufisme di Indonesia terhadap Relasi Guru dan Murid dalam Tradisi Generik Sufism pada Majelis Shalawat Muhammad di Surabaya." Teosofi, Jounal Tasawuf dan pemikiran Islam 5(2) (2015).

Rumadi. "Islam dan Otoritas Keagamaan." Jurnal Walisongo 20 (1) (2012).

Salim, Arskal. Challengin the Secular State: The Islamization of Law in Modern Indonesia. Honolulu: Hawai University Press, 2008.

. "Syariah From Below in Aceh : Islamic Identity and the Right to Self Determination with Comparative Reference to The Moro Islamic Liberation Front (MILF)." Journal of Indonesian and Malay World 32 (92) (2004). 
Sehat Ihsan Shadiqqin. "Tarekat Shiddiqiyah dalam Masyarakat Jawa Pedesaan." Jurnal Subtantia 14(2) (2012).

Shadiqin, Sehat Ihsan. "Dibawah Payung Habib: Sejarah,Ritual, dan PolitikTarekat Syattariyah di Pantai Barat Aceh." Jumal Substantia 19(1) (2017).

Sufi, Rusdi. Tgk. Hasan Krueng Kalee dan Teuku Nyak Arief, Profil Ulama dan Umara Aceh. Banda Aceh: Badan Perpustakaan Provinsi NAD, 2006.

Susanti, Edi. "Krisis Kepemimpinan Kiai atas Kharisma Kiai dalam Masyarakat.” Jurnal Islamica 01(2) (2007).

Syed Muhammad Naguib Al-Attas. The Mysticim of Hamzah Fansuri. Kuala Lumpur: University of Malaysa Press, 1970.

Syihab, Alwi. Islam Sufistik, Islam Pertama dan pengaruh Hingga Kini di Indonesia. Bandung: Mizan, 2001.

Ummah, E. Ova Siti Sofwatul. "Tarekat, Kesalehan Ritual, Spiritual dan Sosial: Praktik Pengamalan Tarekat Syadziliyah di Banten." Jurnal Pemikiran Islam dan Filsafat 15(2) (2018).

Werner Kraus. "The Shattariyya Sufi Brotherhood in Aceh." In Aceh History Politics and Culture, diedit oleh Arndt Graf. Singapore: ISEAS, 2010. 